the chair, 107; against, 17 . (The numbers as counted yesterday were $106-17$.)

I am, Sirs, yours faithfully,

Hurber'T H. Janninas, Secretary.

Chelsez Hospital for Women, Fulbam-road, London, S.W., Dec. 19th, 1895.

\section{THE CASE OF MRS. GUTHRIE.}

\section{To the Editors of THe LANCET.}

Sins,--In THE LANCET of Feb. 16th of this year an appeal : xppeared on behalf of Mrs. Julia Guthrie, widow of the late Professor Guthrie, formerly surgeon to the Westminster and Royal Westminster Ophthalmic Hospitals. This appeal was signed by Mr. Upton of Brighton, who stated that $\mathrm{Mr}$. Brandreth, LL.D., a solicitor, would act as treasurer of any fund which might be raised. In the issue of the following week I wrote pointing out that all surgeons were deeply indebted to the author of the "Commentaries on the isurgery of the Peninsular War," especially for his work on "the subject of hemorrhage and its treatmont. I expressed the hope that Mrs. Guthrie, then serenty-five, would not be allowed to die of want, and suggested that if each of a few surgeons would guarantee her a guinea or two a year the - difficulty would be met. Very little resulted directly from the appeal, but I spoke and wrote to various friends, and was enabled by their kindness to transmit to $\mathrm{Mr}$ Brandreth £25 128. Some six months later, on sending Mr. Brandreth my second subscription, it was returned by an official receiver. Mr. Brandreth had become bankrupt, and there appears to be no hope of recovering the money which he received on behalf of Mrs. Guthrie. I have been informed that at his further examinasion Mr. Brandreth admitted having thus received a considerable sum, one gentlcman alone having given fifty guineas. I have been further assured that Mrs. Guthrie had on Oct. 26th received only $£ 23$ from Mr. Brandreth - not - even so much as had passed through my own hands. I need "nardly say that this result has been a cruel disappointment to Mrs. Guthrie. Had it not been for a little timely help she would now have been not only penniless and without necessary clothes, but in debt. I believe that she is now :again without money. Under these circumstances, I venture -again to ask for help on Mrs. Guthrie's behalf, and to offer to acknowledge and administer any sums which may be sent ro me for her.

134, Harley-street, W. I am, Sirs, yours faithfully, STAXLEY Bord.

\section{$\therefore$ THE ADMIISSION OF WOMEN TO THE ROYAL COLLEGES OF PHYSICIANS OF LONDON AND SURGEONS OF ENGLAND." To the Editors of THE LANCET.}

SIRs,-The letter of Mrs., Miss, or Mr. Marion RitchieII beg his or her pardon, for I have not the honour of his or Ther acquaintance-certainly does not disprove my statement of "facts," but to my mind clearly confirms their accuracy. If am not in the habit of making statements unless they are vacts. How your correspondent is in a position to prove that, as stated, "no medical woman in practice in England has -ever taken less than a guinea" I cannot say; still, I will not go into the question whether this is a fact or not. This "act, however, remains, that "women students," "officered by medical women," attend the poor women of Battersea and "Clapham for a fee of $5 s$., and these poor women believe not only that they are paying "a doctor's fee," but the majority . of them believe that they are going to have a doctor to attend them for this fee. Instead of this they find out, often to their regret afterwards, that they are being practised upon and that they are paying for the privilege into the bargain.

It would be interesting if your correspondent would inform she treasurer of the Hospital Saturday Fund whether they are receiving any of that Fund, and also that they are charging the extreme poor of such a poor parish as Battersea a fee of $5 s$., or as much as they could, to secure the services - of a skilled midwife to replace the unskilled attendance of beginners. It is immaterial to the poor woman whether the ree of $5 s$. is paid " to the funds of the hospital" or goes into the pocket of anyone else. The fact remains that medical women, no matter whether qualified or not, are attending casses of midwifery for a fee of $5 \mathrm{~s}$, at least in Battersea, and
I am informed that some of our poorer brethren, in order to deal with this disgraceful competition of women, are accept. in fees which are almost as low in order to keep the wolf from the door. I sincerely trust that some of them will enlighten us upon the subject. I know of at least one case where an unmarried woman who was pregnant and had engaged a medical man to attend her for a fee of $£ 11 s$, but was attended at one of these so-called hospitals conducted by women. It is this disgraceful competition of socalled hospitals, and their congeners that is helping so largely, not only to pauperise the people, but also to impoverish that noble profession to which we have the honour to belong. I am, Sirs, yours truly, Weymouth-street, W., Dec. 13th, 1895.

A. MoRton.

\section{To the Editors of THE LANCET.}

Srrs, - Will you kindly allow me space to give a point. blank contradiction to the assertion made in a letter signed "Vigilans" in your issue of Dec. 21st, that the Clapham Maternity was originally started as a "private speculation" by a medical woman? It originated in the work of a medical mission opened in Clapham in 1885 by the Church of England Women's Missionary $\Lambda$ ssociation, with the coöperation of several well-known London and Clapham medical men. The post of medical officer for this work was advertised in THE LANCET, and by that means obtained by the lady named by your correspondent, but she was a total stranger to the originators and had no pecuniary interest (beyond her fixed salary) in their arrangements.

\section{I am, Sirs, yours truly,}

\section{Marion Ritchie,}

Hon. Sec., Clapham Maternity.

*** This correspondence must now cease.-ED. L.

\section{"THE CASE OF DR. WIGHT."}

To the Editors of THE LANCET.

SiRs,-I am glad that your correspondent "M.D." has called attention to the omission by the defence in the abore case to call evidence to show that rupture of the uterus may occur in labour irrespectively of all operative interference or during the most careful and skilful manipulations. I can instance a case in point. About three years ago I was called in to attend a primipara forty years of age. The messenger stated that she was in severe continuous pain, and her mother was afraid she was dying. On arrival I found I had to do with a dying woman, apparently suffering from internal hæmorrhage. I injected ether hypodermically and made an examination per vaginam, but could not detect any dilatation of the os. She died in a few minutes. I offered to do Cæsarean section to try to save the child, but the husband would not consent. At the necropsy I found an extensive rupture of the uterus, the walls of which were so thin that they did not appear much thicker than the membranes; in fact, the whole of the nutrition of the uterus seemed to have been expended upon a very large fibroid which involved a large portion of the lower part of the uterus. Had this rupture taken place during a later stage of the case or when forceps were being applied I am afraid it would have been, to say the least of it, unpleasant for me. Dec. 11th, 1895.

$$
\text { I am, Sirs, yours faithfully, }
$$

ANOTHER M.D.

\section{THE SOIL IN RELATION TO DISEASE.}

\section{To the Editors of THE LANCET.}

SiRs,-In your issue of Dec. 14th I have read with the greatest interest Dr. Poore's lecture on the Soil in its Relation to Disease and Sanitation. In common with most officers of the Indian Medical Service I can bear witness to the value of human excrement as manure. In the Bengal gaols, and I believe in most others in India, the whole of the fæcal excrement is trenched in the gaol garden; and these gardens generally yield excellent crops. There is never any unpleasant smell except for a brief period during the "rainy season." Even then the smell is not very noticeable and can be overcome if the trenches are made a little deeper than is necessary at other times of the year. As in the case of Dr. Poore's garden the fæces, covered with earth, are generally merely buried and the "humification" left to nature. This process, however, may be hastened by an excellent scheme which is 
in use in the Presidency Gaol, Calcutta. The superintendent, Mr. P. Donaldson, by an ingenious use of the Archimedean screw, devised a machine in which the freces and earth are most intimately mixed. This mixture is ground out through a hole in the gaol wall and is received into pans. It is carried at once to the garden. I was for some time medical officer to the Presidency Gaol, and I can say without hesitation that I never noticed the least smell in or around the garden. Dr. Poore's well is also very interesting to me, since it carries out and improves upon a principle on which, in my sanitary reports as a civil surgeon, I have always insisted with regard to shallow wells.

I am, Sirs, yours faithfully,

J. H. TULL WALSH,

Roughton, Dec. 18th, 1895. Surgeon-Captain I.M.S.

\section{THE GENERAL MEDICAL COUNCIL.}

\section{To the Editors of THE LANCET.}

SIRs,-On reading in your columns the remarks of Sir Richard Quain as to the disabilities of the legal profession, I could not see that there was any reason for our being content with the present constitution of our Council. Some of us from Lancashire and Cheshire, who were present at its session in May last, certainly were not favourably impressed with what we witnessed. Had we been shareholders in an undertaking having in its employment or government 32,000 hands, we should not have felt satisfied in leaving it in the hands and under the control of such a body of men, neither should we bave felt content that even the affairs of a city would be effectually managed with a similar body of men in its Council. We certainly do hope that those members of our profession who can visit the council chamber during the session will avail themselves of the opportunity, for the public have free access, as they will then see how and by whom the business of the government of the profession in these realms is conducted. Surely there ought to be some limit as to the age when elected. At our Manchester Royal Infirmary the limit for holding appointments is sixty. Is there any reason why some such restriction should not be adopted in our governing body? Surely hundreds of capable and reliable men can be found in the country under that age who have the necessary energy and ability which would command the respect and confidence of every man. As to Sir Richard Quain's remarks about the direct representatives, many of us in this part of the country are of opinion that, if we had had more, we should have had a far more practical outcome of the investigations in reference to medical aid associations than we can find in their report on that question.

One effectual means of bringing the medical officers of such trading institutions into line would be to have an annual registration, as in the legal profession that the president referred to. If the amount of the fee were $5 s$., the Council would have an additional income of about $£ 8000$. This would provide us with ten additional direct representatives, and leave a large balance to be applied to some other useful purpose for the benefit of the profession at large.

It is not necessary to dwell at length on the advantages that would be derived from an annual registration; but this one might be stated, that such men as I have mentioned would at once begin seriously to reflect that it would be absolutely necessary to put their houses in order. For the first year or two there might have to be a prolonged session of the Council or its executive to inquire into the reasons why certain men should not be again licensed to practise, or whether their licences should be endorsed, both as a record and a warning, as is done by the magistrates in certain other licences. But as time went on and better discipline resulted, the extra sessions would become small matters, for members would always feel that they were under the direct control and supervision of the General Medical Council. I am, Sirs, yours faithfully,

Manchester, Dec. 7th, 1895.

G. H. BRoadbent.

Presentation.-Mr. J. Griffiths Whittindale, L.R.C.P., L.R.C.S., district medical officer, Old Calabar, Niger Coast Protectorate, has been presented by the European, residents as a token of the high esteem in which he is beld by them, with a handsome silver-mounted dressingbag for his wife and a canteen of plate and silver-mounted cigar-bo for himself.

\section{THE BATTLE OH' THE CLUBS.-XV. (From our Special Commissioner.) (Continued from p. 15/1.)}

\section{Northampton: The Friendly Societies $\Lambda$ No the} National Medicaj, Aid Company, Limited.

A ${ }^{\top}$ Northampton, next in importance after the Royal Victoria Dispensary, is the Friendly Societies' Medical Institute. The total membership of this important organisation amounted, in 1894, to 13,154. The income for that year was $£ 17372 s .6 d$., and the expenditure $£ 16674 s$. 6d., leaving a surplas of $£ 6918 s$. Out of this expenditure $£ 66016 s .8 d$. were paid to the medical officers of the institute, and as, during the course of the year, they gave 44,192 consultations the medical officers were paid at the average rate of a little over 3 L $d$. per consultation. One of the former medical officers of this institution states that no medical man could manage the work for this and similar institutions unless he is prepared to see from thirty to forty patients per hour at the surgery and to visit from ten to fourteen patients at their own homes also in the course of a single hour. The committee, however, have now resolved to establish some sort of limit to the number of patients to be seen by the officers. They have determined under no circumstance to pay their head medical officer more than $\$ 300$ a year. If the number of members increase they will not augment this salary, but will appoint another assistant medical officer. Actually, there are two assistant medical officers. Some time ago the chief medical officer of this institution resigned because, among other reasons, he objected to the interference in medical affairs of an absolutely incompetent lay committee. At that time the committee consisted of three paper-hangers, three compositors, two barbers, two shoemakers, two porters, one baker, one miller, two clerks, one grocer's assistant, and one ex-policeman. This committee holds in its hands the very conscience of its medical servants. The committee meet and pass resolutions governing the medical service without so much as consulting the medical officers. When the chief medical officer on one occasion protested, the president of the managing committee replied: "You must do what we say while you was in our service." It stands to reason that these medical servants of uneducated lay committees cannot afford to give due consideration to the welfare of the patients. They are not allowed the time necessary to properly examine the patients, neither have they the leisure to read current medical literature and keep themselves posted in the progress of medical science. They must. go on prescribing at express speed and by rule of thumb, and the committees of management are too ignorant. to understand how this degrades the profession and endangers. the health of their members. As for a wage limit, there is none. One of the mayors of Northampton and all his family belonged to, and obtained medical aid from, the Friendly Societies' Medical Institute. A member of this institutedid not scruple to seek its medical aid, though he was able to pay $£ 21$ to a surgeon for a special operation performed upon his wife. A retired publican used to pay guinea fees to a consulting physician, though for ordinary complaints be obtained his medicine from the institute. A Poor-law guardian was also a member of this institute; and men who are too highly placed to join this friendly society for its general benefits send some of their sons to be enrolled as juvenile members. According to the rules, the family of a member can join the friendly society, not necessarily for all benefits, but for the medical aid only. Thus a comparatively rich man, who does not want to subscribe for a sick allow. ance or a funeral fund, enters his son as a member for these benefits; and then, on the strength of this relationship, brings in all the family for the medical aid of the Friendly Societies' Medical Institute. Thus the middle-class element that no longer cares for the ordinary financial benefits given by these friendly societies manages to come in all the same for the medical aid. Yet these are the very people who

1 The previous articles on this subject were published in THE LANCET on the following dates: (1) Aug. 24th, 1895, Brussels; (2) Aug. 31st, 1895, Brussels ; (3) Sept. 21st, 1895, Portsmouth ; (4) Sept. 28th, 1895, Portsmouth ; (5) r.t. 5th, 1895, Eastbourne; (6) Oct. 12th, 1895, Lincoln; (7) Oct. '26th, 1895, Lincoln; (8) Nov, 2nd, 1895, Grimsby; (9) Nov. 9th, 1895, Bexhill-on-Sea ; (10) Nov. 16th, 1895, Hull; (11) Northampton; (14) Dee. 21st, 1895, Fermanagh Medico-Ethical Association. 